\title{
Geotechnical Finite Element Analysis
}


Downloaded by [] on [26/04/23]. Copyright @ ICE Publishing, all rights reserved. 


\section{Geotechnical Finite}

\section{Element Analysis}

\section{A practical guide}

\section{Andrew Lees}

BEng PhD CEng MICE 
Published by ICE Publishing, One Great George Street, Westminster, London SW1P 3AA

Full details of ICE Publishing sales representatives and distributors can be found at: www.icebookshop.com/bookshop_contact.asp

\section{Other titles by ICE Publishing:}

Finite Element Analysis in Geotechnical Engineering: Volume two Application

D. Potts and L. Zdravković. ISBN 978-0-7277-2783-1

Structural Analysis with Finite Elements

P. Rugarli. ISBN 978-0-7277-4093-9

Finite Element Design of Concrete Structures

G. Rombach. ISBN 978-0-7277-3274-3

www.icebookshop.com

A catalogue record for this book is available from the British Library.

ISBN 978-0-7277-6087-6

(c) Thomas Telford Limited 2016

ICE Publishing is a division of Thomas Telford Ltd, a wholly-owned subsidiary of the Institution of Civil Engineers (ICE).

All rights, including translation, reserved. Except as permitted by the Copyright, Designs and Patents Act 1988, no part of this publication may be reproduced, stored in a retrieval system or transmitted in any form or by any means, electronic, mechanical, photocopying or otherwise, without the prior written permission of the publisher, ICE Publishing, One Great George Street, Westminster, London SW1P 3AA.

This book is published on the understanding that the author is solely responsible for the statements made and opinions expressed in it and that its publication does not necessarily imply that such statements and/or opinions are or reflect the views or opinions of the publishers. While every effort has been made to ensure that the statements made and the opinions expressed in this publication provide a safe and accurate guide, no liability or responsibility can be accepted in this respect by the author or publishers.

While every reasonable effort has been undertaken by the author and the publishers to acknowledge copyright on material reproduced, if there has been an oversight please contact the publishers and we will endeavour to correct this upon a reprint.

Commissioning Editor: Laura Balchin

Development Editor: Maria Inês Pinheiro

Production Editor: Rebecca Norris

Market Development Executive: Elizabeth Hobson

Typeset by Academic + Technical, Bristol

Index created by Simon Yapp

Printed and bound in Great Britain by TJ International Ltd, Padstow 
01

How is a geotechnical finite element analysis set up?

1.1. Analysis planning

1.2. Geometry

1.3. Meshing

1.4. Analysis stages

1.5. Constitutive models

1.6. Groundwater and drainage

References

02

How are constitutive models selected?

2.1. Introduction

2.2. Aspects of ground behaviour

2.3. Common constitutive model types

2.4. Typical applications

References

03

How are soil and rock parameters obtained?

3.1. Introduction

3.2. Soil and rock sampling and groundwater measurement

3.3. Parameter testing

3.4. Parameter derivation and validation

Appendix 3.1 - Useful equations in the validation of model or initial state parameters

04

How are groundwater effects taken into account?

4.1. Introduction

4.2. Drained and undrained analyses

4.3. Groundwater flow analyses

4.4. Consolidation analysis

References

05

How are geotechnical structures modelled?

5.1. Structural geometry

5.2. Structural materials

5.3. Soil-structure interaction 
06

Can FE analysis be used with design codes?

6.1. Introduction

163

6.2. Serviceability limit state (SLS)

167

6.3. Geotechnical ultimate limit state (ULS)

168

6.4. Structural limit states

References

07

How is the accuracy of outputs assessed?

183

7.1. Introduction

7.2. Assessing accuracy

188

7.3. Managing errors

192

References

08

\section{Examples}

8.1. Introduction

8.2. Raft foundation with settlement-reducing piles example

8.3. Shaft excavation example

225

8.4. Embankment construction example

243

References

261

Index

263 
It soon became clear to me while coordinating the European Commission Lifelong Learning COGAN Project on improving competency in geotechnical numerical analysis that finite element (FE) analysis is now widely used in geotechnical engineering but, in contrast to other fields of engineering, there are few fulltime users of such software. Geotechnical FE analysis places heavy demands on the competency of engineers but it is difficult to gain sufficient competency when applying such software part-time between other engineering tasks. There was an obvious need for a ready reference for users of geotechnical FE analysis software to learn about and refresh their knowledge on applying the technique in practice. This book is intended primarily to address that need.

Before using this book, it may also be useful to know the following:

- The book is strictly software neutral. I did not want to appear to be favouring any particular software.

- I have not endeavoured to cover the essential background soil mechanics, rock mechanics and geotechnical engineering knowledge needed to perform FE analysis since this can be found readily from other sources.

- Worked examples in FE analysis are complicated to present and explain. So that readers can access information quickly, I have avoided putting examples within the topics in Chapters 1 to 7. Rather, three examples illustrating application of many of the topics are presented and described separately in Chapter 8 .

- Some parts of the NAFEMS guidebook Obtaining Parameters for Geotechnical Analysis which I authored have been reproduced in this book, particularly in Chapter 3, with the kind permission of NAFEMS.

- This book provides the background information covering about 160 competence statements from the COGAN Competency Tracker maintained by NAFEMS. This Competency Tracker is available online to individuals free of charge for monitoring and recording competency in geotechnical numerical analysis. 
Downloaded by [] on [26/04/23]. Copyright @ ICE Publishing, all rights reserved. 


\section{About the author}

Andrew Lees graduated with a BEng in Civil Engineering at the University of Southampton in 1996, where he also obtained a PhD in the fields of centrifuge modelling and FE analysis of soil-structure interaction in 2000. He was then a geotechnical engineer at a major UK consultancy until 2004 when he took up a lectureship at Frederick University, Cyprus where he taught geotechnical engineering until 2015. In 2007, he also set up and continues to run the successful consultancy Geofem, specialising in geotechnical FE analysis. In 2016, he was also appointed Senior Application Technology Manager at Tensar International, where one of his tasks is to improve techniques of modelling geogrid-stabilised soils by $\mathrm{FE}$ analysis. He is a member of the NAFEMS Geotechnical Working Group and authored their first guidebook on obtaining parameters for numerical analysis and is a founding member of the Professional Simulation Engineer scheme administered by NAFEMS. He coordinated the European Commission Lifelong Learning project COGAN on improving competency in geotechnical numerical analysis. He was convener of the evolution group advising the Eurocode 7 committee on the use of numerical methods in accordance with the design code and has since been involved in the redrafting of Eurocode 7. He is a member of the British Geotechnical Association and the Institution of Civil Engineers. 